\title{
A KINETIC SPECTROPHOTOMETRIC ANALYSIS OF OXIDATION OF A POTENTIAL POLLUTANT ORTHO AMINOPHENOL BY POTASSIUM MONOPERSULFATE FOR ITS CONVERSION INTO LESS TOXIC COMPOUND
}

\author{
Manila $^{1}$, R.D. Kaushik ${ }^{2}$, Neha Bhatt ${ }^{1, *}$, Jaspal Singh ${ }^{2}$, Anshu Pal ${ }^{1}$ \\ and Sandhya Sharma ${ }^{1}$ \\ ${ }^{1}$ Department of Chemistry, Kanya Gurukul Campus, Gurukul Kangri Vishwavidyalaya, \\ Hardwar, 249404, (Uttarakhand) India \\ ${ }^{2}$ Department of Chemistry, Gurukul Kangri Vishwavidyalaya, \\ Hardwar, 249404, (Uttarakhand) India \\ *E-mail: nehagairola1992@gmail.com
}

\begin{abstract}
The current study focusses on the uncatalyzed potassium mono persulfate oxidation of ortho aminophenol to develop a method for its removal from water samples affected by it. Kinetic spectrophotometric analysis was done to study the effect of reaction $\mathrm{pH}$, initial ortho aminophenol concentrations, initial oxone (potassium monopersulfate) concentrations, temperature, the effect of solvent and presence of ions in the reaction under study. All the kinetic parameters confirmed the fractional-order kinetic model. Thermodynamic parameters like change in enthalpy, change in entropy, pre-exponential factor, activation energy and Helmholtz free energy were investigated and it has concluded that this oxidation reaction was favorable and endothermic. The activation energy for removal of ortho aminophenol was found to be $74.096 \mathrm{~kJ} / \mathrm{mol}$, which was compared with previous results. The optimum $\mathrm{pH}$ for this process was found to be 7.0 and the temperature was $32-38^{\circ} \mathrm{C}$. Hence, the results suggested that this method could be applied as a low-cost effective method, considering the ease of availability of chemicals, their non-toxic nature, low cost and the period for completion of the reaction.
\end{abstract}

Keywords: Ortho Aminophenol, Oxone, Kinetic, Wastewater, Cost-effective, Less Toxic.

(C) RASĀYAN. All rights reserved

\section{INTRODUCTION}

In this modern era, pollution is a prominent issue and the most dangerous type of this problem stands before us is water pollution. Saltwater covers $71 \%$ of the surface of the Earth and the remaining $29 \%$ freshwater, is used to sustain life. According to WHO (World Health Organization) reports, people more than 1 billion, are not getting clean water. Waterborne diseases are responsible for the death of approx 4000 children per day, as per Health Monitory Authorities. Increasing industrialization and activities of humans are the major factors for polluting the available water sources ${ }^{1}$. The release of waste products as phenols due to the use of carcinogenic aromatic compounds in various industries ${ }^{2}$ is a very serious topic to be discussed. The bulk of the chemical waste, which contaminates the water and environment, has created by the development of industries ${ }^{3}$. Many industries like paper, pulp, cosmetics, textile, food, and pharmaceuticals use azo dyes, which contaminates the wastewater by more than $15 \mathrm{wt} \%{ }^{4}$. The round off figure of commercial dyes is $1,00,000$, while their annual worldwide production is $7 \times 10^{5}$ metric tons.

The direct discharge of $2 \%$ of dyes in water bodies has been reported during their manufacturing process. $10 \%$ of the dyes get lost during the coloration process of textiles ${ }^{5}$. The largest consumer of dyes is textile industries since half of the dyestuff material of the world is consumed by itself only ${ }^{6}$. The treatment of industrial effluent becomes a major environmental problem. Moreover, the discharge of contaminated water to the environment is due to an increase in the growth of the textile industry worldwide ${ }^{7}$. It is because the dyes used in these industries are non-degradable and highly toxic for aquatic life, carcinogenic, and mutagenic to humans or adversely affect human health ${ }^{8}$. The other reasons reported for decreasing the Rasayan J. Chem., 13(3), 1424-1437(2020) http://dx.doi.org/10.31788/ RJC.2020.1335771

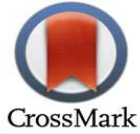


RASĀYAN J. Chem.

Vol. 13 | No. 3 |1424-1437| July - September | 2020

quality of water are the increased population, agricultural and domestic wastes, fast pace of industrialization etc. Moreover, the increasing demand for various products leads to environmental threats. Pollution of water and air has increased by the use of energy generated from fossil fuels ${ }^{9}$. Hence the effluent must be treated properly before it's discharged into water bodies. In this era of crisis of groundwater on earth, the treatment of wastewater and hence use in agriculture becomes an attractive option ${ }^{10}$.

Aminophenols are one of the harmful dyes, that have been used as a dyeing agent for furs, hairs, and leather ${ }^{11,12}$ and in the manufacturing of pharmaceuticals, resulting in their presence in groundwater of the area nearby to industrial plant and may be released in water streams ${ }^{13}$. The toxicity of aminophenols affects humans in more than one way. Skin allergy, headache, fatigue, dizziness, and blue color to the skin and lips $^{11,12}$ are the major effects on humans. In plants, aminophenol disrupts the regular metabolic pathway, leading towards serious deformation as prove in the study ${ }^{14}$. Since the product formed due to oxidation of ortho aminophenol (OAP) i.e. Questiomycin A, having anti-microbial properties, is used for the synthesis of an antineoplastic agent Actinomycin $\mathrm{D}^{15}$. Mixed metastatic embryonal carcinoma of the testes, Wilm, gestational choriocarcinoma, etc. are some of the examples of tumors, which are treated by Actinomycin $\mathrm{D}^{16-18}$. Hence, the study becomes all the more important to be seriously explored.

In this way, many physical, chemical, and biological methods are used. These methods are reported as follows-

\section{- By Metallic Oxidation}

Using transition metal complexes for the conversion of OAP to 2-amino-3H-phenoxazin-3-one (APX) for the biosynthesis of actinomycin D has become an area of great interest. Many metals were used in their compound form, as a catalyst for the oxidative process of OAP. Many compounds of copper have been used as catalysts for the oxidation of OAP in DMF at $60^{\circ} \mathrm{C}$ with dioxygen as an oxidant, for example$\mathrm{Cu}(\mathrm{OAc})_{2}, \mathrm{Cu}\left(\mathrm{OCH}_{3}\right)(\mathrm{Cl}), \mathrm{CuSO}_{4}, \mathrm{CuCl}, \mathrm{CuCl}_{2}, \mathrm{Cu}\left(\mathrm{OCH}_{3}\right)_{2}$ and $\mathrm{Cu}\left(\mathrm{NO}_{3}\right)_{2}{ }^{19}$. Copper (II) catalyzed oxidation of OAP in aqueous solution has also investigated through spectrophotometer ${ }^{20}$. By using cobalt (II) phthalocyaninetetrasodiumsulfonate as a catalyst, oxidation of OAP has been done ${ }^{21}$. By forming an intermediate as o-benzoquinone imine, oxidation of OAP has performed by using $\mathrm{K}_{3} \mathrm{Fe}(\mathrm{CN})_{6}{ }^{22}$. Ti has been used as $\mathrm{TiO}_{2}$ during heterogeneous UV photolysis in the removal process. Some enzyme-catalyzed methods were also used in this way. The Use of tyrosinase as a catalyst for the mechanistic study of OAP has been reported $^{23}$. Haemoglobin, catalase etc., for the oxidation purpose of OAP, have the efficient quality to act as catalysts ${ }^{24}$. Ag as Ag electrode by using SERS (Surface-enhanced Raman scattering) technique ${ }^{25}$ and $\mathrm{Pt}$ as a Pt electrode was used in the electrochemical oxidation of para, ortho and meta aminophenols in acidic medium by spectroelectrochemical method ${ }^{26}$.

\section{- By Adsorption Method}

Adsorption on activated carbons has been investigated to oxidize phenols ${ }^{27}$. The kinetic study by using groundnut shells as the biomass was also investigated ${ }^{28}$. Novel adsorbents as carbon were used for removal of OAP and to investigate its kinetic study ${ }^{29}$.

- Ozone $\left(\mathrm{O}_{3}\right)$ had been used during the oxidative process for the generation of hydroxyl free radical ${ }^{24}$. Moreover, it has been applied for the investigation of the degradation of 4-chloro-2-aminophenol by the help of ultrasonic reactors and photolysis process ${ }^{30}$.

- Radiolysis was another way out, by using a source of radiation having high energy ${ }^{24}$.

- Wet air oxidation is also applied for the oxidation of OAP. It involves oxidation at elevated temperature $\left(125-320^{\circ} \mathrm{C}\right)$ and pressure $(0.5-20 \mathrm{MPa})$, using $\mathrm{air}^{24}$.

- By Using Nanoparticles as a Catalyst

Mn-doped $\mathrm{ZrO}_{2}$ nanoparticles have been used for the abatement of degradation of dye ${ }^{3}$. Carbon-based nanocomposites like Carbon quantum dots have been used for environmental remediation ${ }^{9}$. $\mathrm{TiO}_{2}$-hybrid nanomaterials have been used for enhanced photocatalysts for water remediation ${ }^{4}$.

\section{- MBSPs Technique}

This technique of remediation of pollutants covers microfiltration (MF), ultrafiltration (UF), nanofiltration (NF), reverse osmosis (RO) and forward osmosis (FO). It includes membrane bioreactors and photocatalytic membrane reactors (PMRs) also ${ }^{1}$. 
RASĀYAN J. Chem.

Vol. 13 | No. 3 |1424-1437| July - September | 2020

Due to the strong oxidizing nature, caroat or oxone has a wide range of applications. The sulfur atom present in its structure is tetrahedrally surrounded by per hydroxyl and hydroxyl groups ${ }^{31}$. A triple salt of potassium monopersulfate, potassium hydrogen sulfate ,and potassium sulfate, has a long storage life. Since it does not contain any halogen, by-products after the oxidative process do not contain any halogen. Along with use for denture cleaners, metal treatment and metal extraction, etching of printed circuit boards, repulping of papers, pretreatment of wool, and swimming pool water treatment ${ }^{32}$, it has wide applications in processes of removal of toxic chemicals from wastewater. Oxone associated metalloporphyrins were used for oxidizing acetaminophen and ellipticine derivatives ${ }^{33}$. Pharmaceutical compounds like acetaminophen, antipyrine, doxycycline ,etc have been oxidized by oxone in both catalyzed and uncatalyzed manner ${ }^{34}$. Kinetic spectrophotometric method for determining doxycycline hyclate was performed by using Mn (II) as catalyst ${ }^{35}$. Degradation of ibuprofen has carried out by oxone ${ }^{36}$. For oxidative cyclization of 2aminobenzoic acid and aryl aldehydes to aryl 4H-3,1-benzoxazin-4-ones, environmentally benign oxidant oxone has been used ${ }^{37}$. It was also used to improve sludge dewaterability along with the use of $\mathrm{Fe}(\mathrm{II})^{38}$. Salts like diaryliodonium was synthesized by using oxone ${ }^{39}$.

Removal of NO from flue gas by the help of sulfate and hydroxyl free radicals was achieved by activating oxone with cobalt ${ }^{40}$. It has also been used for studying reactions of alkynylsilane ${ }^{41}$. Its use as an oxidant for synthesizing a variety of carbamates from amines, alcohols, and carbon mono oxide by $\mathrm{Rh}$ as a catalyst ${ }^{42}$. Synthesis of indeno[1,2,3-de]chromenes class of compounds has been done using oxone as a terminal oxidant $^{43}$. The use of oxone has also been reported for the synthesis of Ni-based water oxidizing electrode ${ }^{44}$. Oxidation of phenols in water was carried out by sulfate radicals by the support of Ru catalysts. These sulfate radicals were generated from oxone ${ }^{45}$. Degradation and mineralization processes of Acid Blue (113) wastewater was done by UV/oxone and UV/persulphate ${ }^{46}$. Oxidative cyclization of 2-92arylidenehydrazinyl) pyridines chemoselectively has been done by $\mathrm{RuCl}_{3} /$ oxone. It acts as an efficient homogeneous catalyst ${ }^{47}$. The use of oxone in wet air oxidation of landfill leachates has been reported ${ }^{48}$. Till now, oxone has not been used for oxidizing OAP. Here, we have attempted removing OAP and to convert it to actinomycin D.

In the present work, we have investigated the removal of OAP, by using low-cost chemicals at normal temperature condition, conducted the kinetic and thermodynamic studies to understand its behavior. This way of removal is performed at low operational cost and found to be eco-friendly in all respects.

\section{Limitation and Novelty}

Although the removal of pollutant OAP has been done by using various chemical and adsorptive methods, but its kinetic study of removal by using oxone is not found in the literature. Oxone acts as a potent oxidizing agent, which readily oxidizes OAP into product APX. It does not require any catalyst during the reaction. Furthermore, the chemicals used for the present work were non-toxic and easily available. Although the present work is very rapid and accurate, but still it has some limitations.

- The suitable $\mathrm{pH}$ range for reaction mixture, when the medium is buffered by phosphate buffer, is $6-7^{49}$ at $32^{\circ} \mathrm{C}$.

- Highly concentrated buffer is a must, since the product $\mathrm{HSO}_{4}^{-}$, after decomposition of oxone, is a much stronger acid than the reactant $\mathrm{HSO}_{5}^{-}$. A highly concentrated buffer maintains the constant $\mathrm{pH}$ of the reaction mixture.

- The concentration of oxone must be at least 10 times higher than [OAP].

\section{EXPERIMENTAL}

\section{Materials}

Reagent "OAP" was Sigma Aldrich make. "Oxone" i.e. $\mathrm{KHSO}_{5}$ was also Sigma Aldrich make. Other chemicals such as potassium dihydrogen orthophosphate $\left(\mathrm{KH}_{2} \mathrm{PO}_{4}\right)$, sodium hydroxide $(\mathrm{NaOH})$, acetone, and sodium chloride $(\mathrm{NaCl})$ were obtained from Fischer Scientific. All of them were of AR grade. Triply distilled water was used during all the experiments. All the solutions were freshly prepared before use.

\section{Apparatus}

UV-VIS spectrophotometer (SYSTRONICS-118) was used for the analysis. The water bath used for maintaining temperature and for proper mixing of the reaction mixture. The $\mathrm{pH}$ of the reaction mixture 
RASĀYAN J. Chem.

Vol. 13 | No. 3 |1424-1437| July - September | 2020

was maintained by using SYSTRONICS-Digital $\mathrm{pH}$ meter - 335. The Infrared spectra of solid APX were recorded in the wavelength ranges between $4000-400 \mathrm{~cm}^{-1}$ at room temperature in $\mathrm{KBr}$ powder on SHIMADZU FTIR-8400S.

\section{Preparation of Buffer}

Potassium dihydrogen orthophosphate buffer of $0.5 \mathrm{M}$ strength having $\mathrm{pH} 4.0$, was prepared in a $100 \mathrm{ml}$ volumetric flask. $6.8045 \mathrm{gm}$ of $\mathrm{KH}_{2} \mathrm{PO}_{4}$ was dissolved in triply distilled water and made up to $100 \mathrm{ml}$ in a volumetric flask. The $\mathrm{pH}$ of this buffer was maintained to be 7.0 by using sodium hydroxide solution, prepared by dissolving $\mathrm{NaOH}$ pellets in triply distilled water.

\section{Experiments for Kinetic Study of Oxidation of OAP}

A reaction mixture was prepared to determine the absorption maxima and to understand the order w.r.t. the substrate as well as oxidant, the effect of $\mathrm{pH}$, effect of temperature, the effect of solvent and effect of ionic strength on the rate of reaction .For the determination of absorption maxima, a reaction mixture was

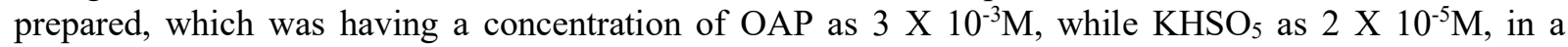
phosphate-buffered medium for the reaction. The reaction was proceeded at $32^{\circ} \mathrm{C}$ for 240 minutes for wavelength ranges from 200 to $800 \mathrm{~nm}$. This experiment gave a value of absorption maxima at which absorbance of each concentration and each variation of parameters was determined.

For determining the $\mathrm{pH}$ effect on the oxidation of OAP, a reaction mixture having substrate strength as $2 \mathrm{X}$ $10^{-5} \mathrm{M}$, while oxidant strength as $2.0 \times 10^{-4} \mathrm{M}$ was prepared for different initial $\mathrm{pH}$ ranging from 4.5 to 10.0 . The optimum $\mathrm{pH}$ for removal of OAP was determined by this experiment.

The order of reaction concerning substrate was investigated by preparing a reaction mixture, in which concentration of oxidant was kept to be constant i.e. 2 X $10^{-5} \mathrm{M}$, while the concentration of the substrate was varied from $3 \times 10^{-4} \mathrm{M}$ to $9 \times 10^{-4} \mathrm{M}$. The order of the reaction was determined and all the subsequent experiments were performed for the order of the reaction. The order of reaction concerning oxidant was investigated similarly, by keeping the strength of the substrate to be constant i.e. $2 \times 10^{-5} \mathrm{M}$ and varying the concentration of oxidant from $2 \times 10^{-4} \mathrm{M}$ to $7 \times 10^{-4} \mathrm{M}$. The $\mathrm{pH}$ for this experiment was maintained as obtained from the previous experiment.

The effect of temperature on the removal of OAP was investigated at $305,307,309$, and $311 \mathrm{~K}$. In this experiment, the concentration of OAP was $2 \times 10^{-5} \mathrm{M}$ and $\mathrm{KHSO}_{5}$ was $2 \times 10^{-4} \mathrm{M}$. The data obtained was used for calculating all the thermodynamic parameters.

Investigating the effect of solvent on reaction, a reaction mixture having substrate concentration $4 \times 10^{-5} \mathrm{M}$ and oxidant concentration $4 \times 10^{-4} \mathrm{M}$, was prepared. Keeping all other conditions constant, here the concentration of acetone was varied as $2.5 \%, 5.0 \%, 7.5 \%$ and $10.0 \%$. Since the reaction mixture was a binary and contained some amount of acetone along with water, hence it was needful to discuss the effect of acetone on oxidation of OAP.

To investigate the effect of ions on the oxidation process of OAP, Na ions were taken in its chloride form $(\mathrm{NaCl})$. During this experiment, the concentration of $\mathrm{Na}$ ions was varied from $2 \times 10^{-1} \mathrm{M}$ to $5 \times 10^{-1} \mathrm{M}$. The reaction mixture for this experiment was containing 4 X $10^{-5} \mathrm{M}$ OAP and $4 \times 10^{-4} \mathrm{M} \mathrm{KHSO}_{5}$. The $\mathrm{pH}$ was remaining the same and the experiment was performed at room temperature i.e. $305 \mathrm{~K}$.

\section{Experimental Calculation}

The order of the reaction was determined by the slope of the graph plotted between $\log k_{o b s}$ and $\log$ [reactant]. As the $k_{o b s}$ (pseudo-fractional-order rate constant) values were essential to determine all the kinetic parameters, Guggenheim method ${ }^{50}$ had been applied to find $k_{o b s}$ values.

Guggenheim method: Guggenheim suggested this method of obtaining rate constant in cases where the final concentration of product or reactant is failed to be calculated experimentally. In this method, a series of absorbance readings (which is equivalent to the concentration of product), At, where $t$ is time with equal intervals, are noted down. Another series of readings $\mathrm{A}(\mathrm{t}+\Delta \mathrm{t})$ is made, each at the time $(\mathrm{t}+\Delta \mathrm{t})$, here $\Delta \mathrm{t}$ is arbitrary chosen constant time interval. Now a plot between $\log [\mathrm{A}(\mathrm{t}+\Delta \mathrm{t})-\mathrm{At}]$ and $\mathrm{t}$ should give a straight line, having slope as $-k_{o b s} / 2.303$.

Evaluation of overall rate constant: 
RASĀYAN J. Chem.

Vol. 13 | No. 3 |1424-1437| July - September | 2020

$$
k_{\text {cat }}=k_{\text {obs }} /[\mathrm{S}] \cdot[\text { catalyst }]
$$

Where, $[\mathrm{S}]$ is concentration of reactant taken in excess and $k_{c a t}$ was calculated overall rate constant. Since this oxidation process was uncatalyzed, hence-

The unit of $k_{\text {cat }}$ was given in $\mathrm{dm}^{3} \mathrm{~mol}^{-1} \mathrm{~s}^{-1}$.

$$
k_{c a t}=k_{o b s} /[\mathrm{S}]
$$

\section{Evaluation of Thermodynamic Parameters}

The plot relating temperature and the specific rate was drawn between $\log k_{c a t}$ and $1 / T$ for testing the validity of Arrhenius equation viz.

$$
\log k_{c a t}=[-E a / 2.303 R T]+\text { Constant }
$$

Where Ea- Activation energy, R- Gas constant and T- Temperature

The slope of this curve gave $E a$, which was also calculated by following formula-

$$
\log \left[\left(k_{\text {cat }}\right)_{2} /\left(k_{\text {cat }}\right)_{1}\right]=[E a / 2.303 R] \cdot\left[1 / T_{1}-1 / T_{2}\right]
$$

Where $\left(k_{\text {cat }}\right)_{1}$ and $\left(k_{\text {cat }}\right)_{2}$ were calculated overall rate constants at temp. $\mathrm{T}_{1}$ and $\mathrm{T}_{2}$. The unit of $E a$ was given in $\mathrm{kJmol}^{-1}$.

Other thermodynamic parameters were as follows-

Frequency factor $(A)$,

$$
k_{c a t}=A \cdot e^{(-E a / R T}
$$

The unit of A was given in $\mathrm{dm}^{3} \mathrm{~mol}^{-1} \mathrm{~s}^{-1}$.

Helmholtz free energy $(\Delta F)$,

$$
k_{c a t}=\left[K_{b} T / h\right] \cdot e^{(-\Delta F / R T)}
$$

Where $\mathrm{K}_{\mathrm{b}}$ - Boltzmann constant and h- Planck's constant. The unit of $\Delta \mathrm{F}$ was given in $\mathrm{kJmol}^{-1}$.

Entropy of activation $(\Delta S)$,

The unit of $\Delta \mathrm{S}$ was given in $\mathrm{Jmol}^{-1} \mathrm{~s}^{-1}$.

$$
k_{c a t}=\left(K_{b} T / h\right) \cdot e^{(-E a / R T)} e^{(-\Delta S / R)}
$$

Enthalpy of activation $(\Delta H)$

The unit of $\Delta \mathrm{H}$ was given in $\mathrm{kJmol}^{-1}$.

$$
\Delta H=\Delta F+T \cdot \Delta S
$$

\section{Evaluation of Dielectric Constant}

For a binary reaction mixture, having acetone and water, the effect of acetone on the rate of oxidation of ortho aminophenol was determined. It was calculated by the following equation:

$$
\mathrm{D}=[(\mathrm{Va} X \mathrm{Da})+(\mathrm{Vw} X \mathrm{Dw})] /(\text { total volume of reaction mixture })
$$

Where, Va- the volume of acetone present in the reaction mixture, Da- dielectric constant of acetone at $305 \mathrm{~K}, \mathrm{Vw}$ - the volume of water present in the reaction mixture, Dw- dielectric constant of water at $305 \mathrm{~K}$.

\section{Evaluation of Ionic Strength}

Ionic strength i.e. the effect of $\mathrm{Na}$ ions on the rate of oxidation was determined by varying the concentration of sodium chloride $(\mathrm{NaCl})$ in the reaction mixture. The ionic strength was calculated by the following equation-

Where $\mathrm{Ci}$ - concentration of ions, $\mathrm{Zi}$ - charge on ions.

$$
\mu=1 / 2 \cdot \sum\left(\mathrm{C}_{\mathrm{i}} \mathrm{Z}_{\mathrm{i}}^{2}\right)
$$

\section{RESULTS AND DISCUSSION}

UV-VIS Analysis

To identify the possible intermediates, an absorption spectrum of the reaction mixture was recorded at different time intervals. The spectrum is given in Fig.-1. An absorption band was observed nearby 200nm, 
RASĀYAN J. Chem.

Vol. 13 | No. 3 |1424-1437| July - September | 2020

when it was recorded for mixture having $\mathrm{KHSO}_{5}$ (oxidant) in buffer i.e. in the absence of OAP, whereas when recorded for mixture having OAP and oxone in phosphate buffer, a redshift occurred. An adduct established here. The characteristic wavelength for this adduct in the visible range was found to be $434 \mathrm{~nm}$, which was attributed to the product APX (2-aminophenoxazin-3-one) $)^{51}$, where the substrate has no absorption.

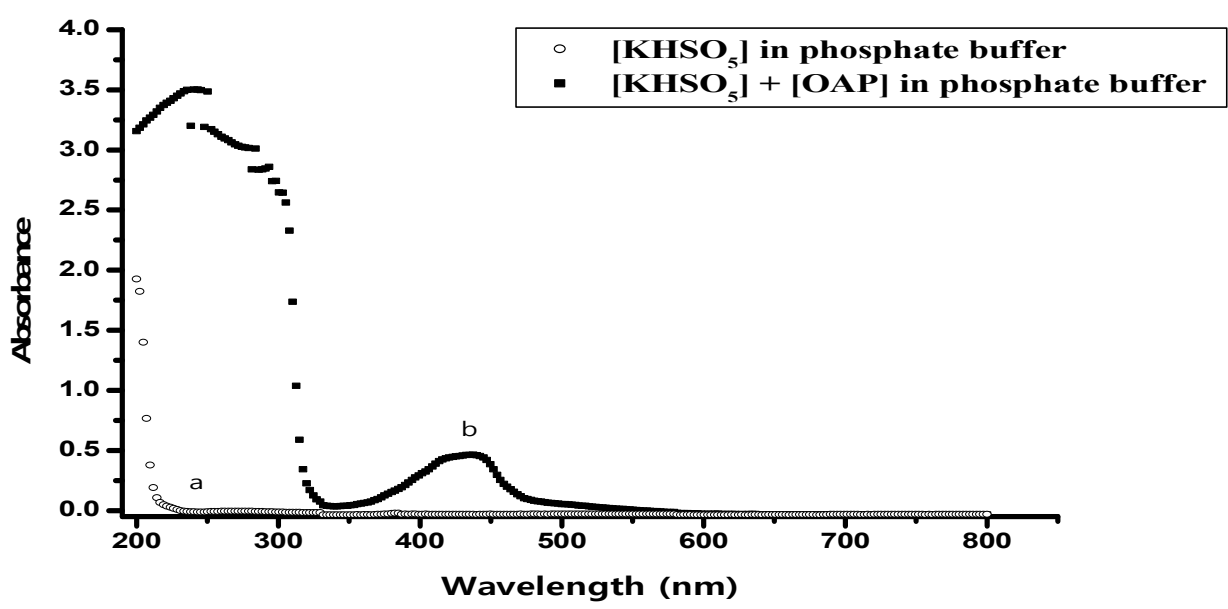

Fig.-1: UV-VIS Absorption Spectrum of Uncatalyzed OAP Degradation by PMS

(a) Absorption Spectrum of $\left[\mathrm{KHSO}_{5}\right]\left(2 \times 10^{-5} \mathrm{M}\right)+$ Phosphate Buffer $(0.5 \mathrm{M})$, (b) Absorption Spectrum of [OAP]

\section{IR-Analysis}

$\left(3 \mathrm{X} 10^{-3} \mathrm{M}\right)+\left[\mathrm{KHSO}_{5}\right]\left(2 \times 10^{-5} \mathrm{M}\right)+$ Phosphate Buffer $(0.5 \mathrm{M})$.

The IR spectra of the reaction mixture was having peaks in the region $3487.42,3161.43,1749.49,1550.82$. 1176.02 and 1018 , which was compared with the literature data ${ }^{52} .1749 .49$ peak lied in the range of stretching for the $\mathrm{C}=\mathrm{O}$ group. The stretching frequency for the $\mathrm{N}-\mathrm{H}$ bond was indicated by 3487.42 . Similarly, the stretching frequency for the C-N bond lies in the range 1080-1360. The ether group present in the product was having a peak range of 1000-1300. All the peaks mentioned above was lying within these ranges, which resembled the structure to be APX.

\section{Rate Law}

The order of the reaction was determined to understand the path or mechanism of the process. The orders concerning substrate and oxidant were shown in Fig.-2 and Fig.-3.

A simple rate law for the uncatalyzed reaction of OAP with $\mathrm{KHSO}_{5}$ was given as-

$-\mathrm{d}[\mathrm{OAP}] / \mathrm{dt}=\mathrm{d}[\mathrm{APX}] / \mathrm{dt}=\mathrm{k}[\mathrm{OAP}]^{\mathrm{n}}{ }_{1}\left[\mathrm{KHSO}_{5}\right]^{\mathrm{n}}{ }_{2}$

Where $\mathrm{n}_{1}$ was the order of reaction w.r.t. substrate while $\mathrm{n}_{2}$ was the order of reaction concerning oxidant.

To find the order concerning substrate and oxidant, kinetic runs were performed by using different oxidants [Table-1: Experiment no. 1 to 6] and substrate concentrations [Table-1: Experiment no. 7 to 13]. Assuming constant concentration of oxidant, pseudo-fractional-order rate law was derived, where,

$k_{o b s}=\mathrm{k}\left[\mathrm{KHSO}_{5}\right]_{2}^{\mathrm{n}_{2}}$

$-\mathrm{d}[\mathrm{OAP}] / \mathrm{dt}=k_{o b s}[\mathrm{OAP}]^{\mathrm{n}}{ }_{1}$

The plot between $\log k_{o b s}$ and $\log$ [OAP] was linear with a correlation coefficient of $\mathrm{R}=98.84 \%$, indicating that the reaction was of fractional-order concerning substrate concentration. $k_{o b s}$ and $k_{c a t}$ indicated the observed and calculated rate constant values. This indicated that $\mathrm{n}_{1}=0.60$ (Fig.-2).

Similarly, assuming the constant concentration of substrate, again pseudo-fractional-order rate law was derived, where,

$k_{o b s}=\mathrm{k}[\mathrm{OAP}]^{\mathrm{n}}{ }_{1}$

$-\mathrm{d}[\mathrm{OAP}] / \mathrm{dt}=k_{o b s}\left[\mathrm{KHSO}_{5}\right]^{\mathrm{n}}{ }_{2}$

OXIDATION OF A POTENTIAL POLLUTANT ORTHO AMINOPHE

Manila et al. 
RASĀYAN J. Chem.

Vol. 13 | No. 3 |1424-1437| July - September | 2020

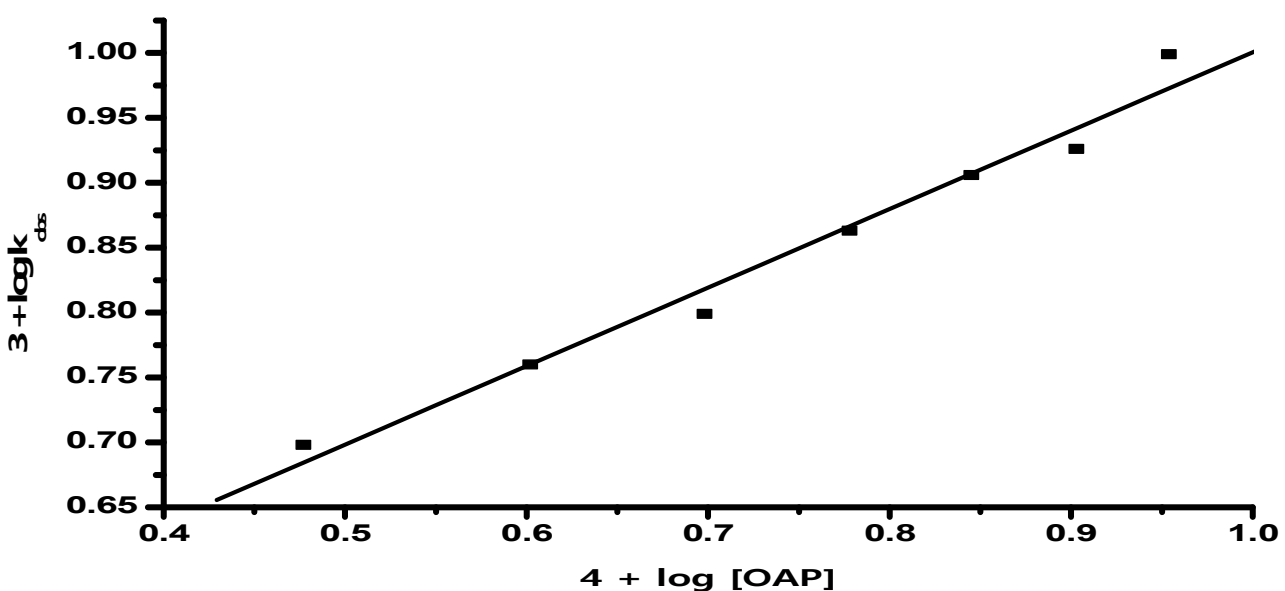

Fig.-2: Plots between $\log \mathrm{k}_{\mathrm{obs}}$ Vs $\log$ [OAP]: Determination of Order Conditions: $\left[\mathrm{KHSO}_{5}\right] \mathrm{X} 10^{5}=2.0 \mathrm{M}, \mathrm{pH}=7.0, \lambda_{\max }=434 \mathrm{~nm}$, Temp. $=32 \pm 0.1^{\circ} \mathrm{C}$

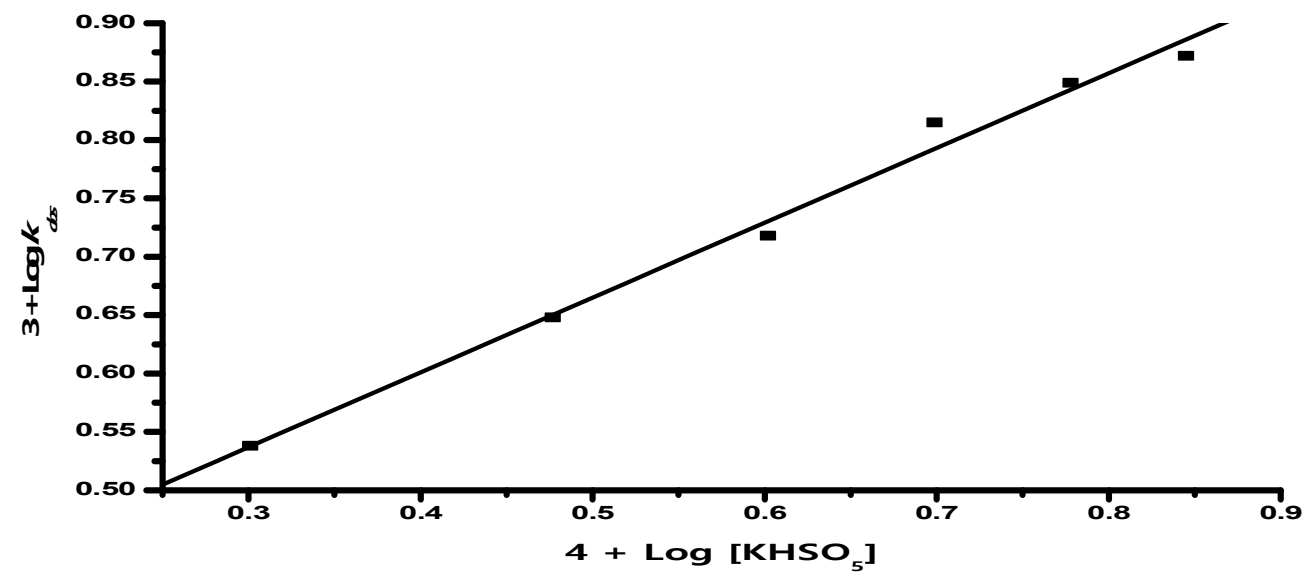

Fig.-3: Plots between $\log \mathrm{k}_{\text {obs }}$ vs $\log \left[\mathrm{KHSO}_{5}\right]$

Conditions: $[\mathrm{OAP}] \mathrm{X} 10^{5}=2.0 \mathrm{M}, \mathrm{pH}=7.0, \lambda_{\max }=434 \mathrm{~nm}$, Temp. $=32 \pm 0.1^{\circ} \mathrm{C}$

Experiments for different oxidant concentrations [Table-1: Experiment no.- 1 to 6] showed that the reaction was again fractional-order concerning oxidant. Again graph plotted between $\log k_{o b s}$ and $\log \left[\mathrm{KHSO}_{5}\right]$ came out to be a straight line with a correlation coefficient of $\mathrm{R}=99.47 \%$ (Fig.-3), through which the order was found to be $\mathrm{n}_{2}=0.64$. Hence the obtained kinetic data revealed that the overall order of oxidation of OAP by oxone was 1.24 with $\mathrm{n}_{1}=0.60$ and $\mathrm{n}_{2}=0.64$ in equation (1); through which mean value of kinetic constant $\mathrm{k}=1.304 \times 10^{-1} \mathrm{~mol} / \mathrm{L} / \mathrm{s}$ at $305 \mathrm{~K}$ was found (Table-1).Table-1 shows a kinetic data for variation of initial OAP concentrations, initial oxone concentrations, the effect of $\mathrm{pH}$, the effect of change in acetone concentration and effect of change in concentration of competitive ions.

Table-1: Kinetic Data for Potassium monopersulfate Oxidation of OAP at $32^{\circ} \mathrm{C}$

\begin{tabular}{c|c|c|c|c|c|c|c}
\hline $\begin{array}{c}\text { Experiment } \\
\text { No. }\end{array}$ & $\begin{array}{c}10^{4} \\
{\left[\mathrm{KHSO}_{5}\right]^{a}} \\
\left(\mathrm{~mol} \mathrm{dm}^{-3}\right)\end{array}$ & $\begin{array}{c}10^{4}[\mathrm{OAP}]^{\mathrm{a}} \\
\left(\mathrm{mol} \mathrm{dm}^{-3}\right)\end{array}$ & $\mathrm{pH}$ & $\begin{array}{c}\text { Acetone } \%^{\mathrm{a}} \\
(\mathrm{V} / \mathrm{V})\end{array}$ & $\begin{array}{c}\mathrm{NaCl} \%^{\mathrm{a}} \\
(\mathrm{W} / \mathrm{V})\end{array}$ & $\begin{array}{c}10^{3} \\
\mathrm{k}_{\mathrm{obs}} \\
/ \mathrm{sec}\end{array}$ & $\begin{array}{c}10^{-1} \mathrm{k}_{2} \\
\left(\mathrm{dm}^{3} \mathrm{~mol}^{-}\right. \\
\left.{ }^{1} \mathrm{~s}^{-1}\right)\end{array}$ \\
\hline 1 & 2.0 & 0.2 & 7.0 & - & - & 3.448 & 1.724 \\
\hline 2 & 3.0 & 0.2 & 7.0 & - & - & 4.452 & 1.484 \\
\hline
\end{tabular}


RASĀYAN J. Chem.

Vol. 13 | No. 3 |1424-1437| July - September | 2020

\begin{tabular}{c|c|c|c|c|c|c|c}
\hline 3 & 4.0 & 0.2 & 7.0 & - & - & 5.220 & 1.305 \\
\hline 4 & 5.0 & 0.2 & 7.0 & - & - & 6.525 & 1.305 \\
\hline 5 & 6.0 & 0.2 & 7.0 & - & - & 7.062 & 1.177 \\
\hline 6 & 7.0 & 0.2 & 7.0 & - & - & 7.446 & 1.064 \\
\hline 7 & 0.2 & 3.0 & 7.0 & - & - & 4.99 & 1.663 \\
\hline 8 & 0.2 & 4.0 & 7.0 & - & - & 5.76 & 1.440 \\
\hline 9 & 0.2 & 5.0 & 7.0 & - & - & 6.29 & 1.258 \\
\hline 10 & 0.2 & 6.0 & 7.0 & - & - & 7.29 & 1.215 \\
\hline 11 & 0.2 & 7.0 & 7.0 & - & - & 8.06 & 1.151 \\
\hline 12 & 0.2 & 8.0 & 7.0 & - & - & 8.44 & 1.055 \\
\hline 13 & 0.2 & 9.0 & 7.0 & - & - & 9.98 & 1.109 \\
& & & & & & & 1.304 \\
\hline 14 & 2.0 & 0.2 & 4.5 & - & - & 1.228 & 6.141 \\
\hline 15 & 2.0 & 0.2 & 5.0 & - & - & 1.842 & 9.212 \\
\hline 16 & 2.0 & 0.2 & 5.5 & - & - & 2.994 & 14.969 \\
\hline 17 & 2.0 & 0.2 & 6.0 & - & - & 2.764 & 13.818 \\
\hline 18 & 2.0 & 0.2 & 6.5 & - & - & 2.994 & 14.969 \\
\hline 19 & 2.0 & 0.2 & 7.0 & - & - & 15.584 & 77.918 \\
\hline 20 & 4.0 & 0.4 & 7.0 & 2.5 & - & 5.22 & 13.05 \\
\hline 21 & 4.0 & 0.4 & 7.0 & 5.0 & - & 6.986 & 17.465 \\
\hline 22 & 4.0 & 0.4 & 7.0 & 7.5 & - & 8.291 & 20.728 \\
\hline 23 & 4.0 & 0.4 & 7.0 & 10.0 & - & 9.673 & 24.183 \\
\hline 24 & 4.0 & 0.4 & 7.0 & - & 0.2 & 4.376 & 10.939 \\
\hline 25 & 4.0 & 0.4 & 7.0 & - & 0.3 & 5.527 & 13.818 \\
\hline 26 & 4.0 & 0.4 & 7.0 & - & 0.4 & 6.909 & 17.272 \\
\hline 27 & 4.0 & 0.4 & 7.0 & - & 0.5 & 7.370 & 18.424 \\
\hline
\end{tabular}

$a$ in $25 \mathrm{ml}$ reaction mixture.

$b$ mean value of kinetic constant $\mathrm{k}$.

\section{Effect of $\mathbf{p H}$}

A plot between $k_{\text {cat }}$, calculated by the Guggenheim method, as a function of different initial $\mathrm{pH}$ of the reaction mixture, ranging from 4.5 to 7.0, is shown in Fig.-4. The figure depicted that the highest value of $\log k_{\text {cat }}$ has been obtained at neutral $\mathrm{pH}$. The value was increased on increasing the $\mathrm{pH}$ of the reaction mixture and found maximum as $\log (60.26)=1.780$ at $\mathrm{pH} 7.0$. Hence, the optimum value of $\mathrm{pH}$ is found to be 7.0. Beyond $\mathrm{pH} 7.0$, the aqueous solution of CAROAT i.e. oxone, becomes unstable ${ }^{32}$.

Although $\mathrm{KHSO}_{5}$ is more stable in acidic conditions, when its aqueous solution was added to the reaction mixture, it is assumed that its maximum stability is found at $\mathrm{pH} \mathrm{7.0,} \mathrm{where} \mathrm{it} \mathrm{is} \mathrm{dissociated} \mathrm{into} \mathrm{its} \mathrm{ionic}$ form i.e. the hydrogen sulfate content is increased and maximum amount of oxygen is generated and hence rate of the reaction becomes maximum at $\mathrm{pH} 7.0$, while in alkaline conditions, the decomposition is delayed due to a drop in the stability of oxone.

Above $\mathrm{pH} 7$ or apparently above 8, phosphate buffer was less effective. The average rate constant in acidic stream i.e. in phosphate buffer for the decomposition of $\mathrm{KHSO}_{5}$ was found to be maximum at $33.2^{\circ} \mathrm{C}$, whereas in basic stream i.e. in carbonate buffer, it was maximum at $25^{\circ} \mathrm{C}^{49}$. Since we had performed all the experiments at $32^{\circ} \mathrm{C}$ in phosphate buffer, hence the acidic range was more appropriate. Between $\mathrm{pH} 7-10$, the decomposition of $\mathrm{KHSO}_{5}$ was second-order, between 6-8 and 10.5 to 12, in the basic stream, it was the first order ${ }^{49}$. Hence, a medium of neutral $\mathrm{pH}$ was found to be an optimum condition for the maximum degradation of OAP.

\section{Effect of Solvent}

The effect of dielectric constant on the reaction rate was studied by adding varying proportions of acetone $(2.5 \%-10 \% \mathrm{v} / \mathrm{v})$. On increasing concentration of acetone, the rate also increases ${ }^{53}$, and results are shown in table (1). A linear plot with $\mathrm{R}=98.57 \%$ with a positive slope is obtained between $\log k_{\text {obs }}$ and $1 / \mathrm{D}$, which is shown in Fig.-5. 
RASĀYAN J. Chem.

Vol. 13 | No. 3 |1424-1437| July - September | 2020

The change in the concentration of acetone in the reaction mixture had a positive effect on the degradation of OAP. The plot between $\log k_{o b s}$ and 1/D is linear with a positive slope, which indicates a positive ion and a dipole nature of rate-determining step ${ }^{54}$.

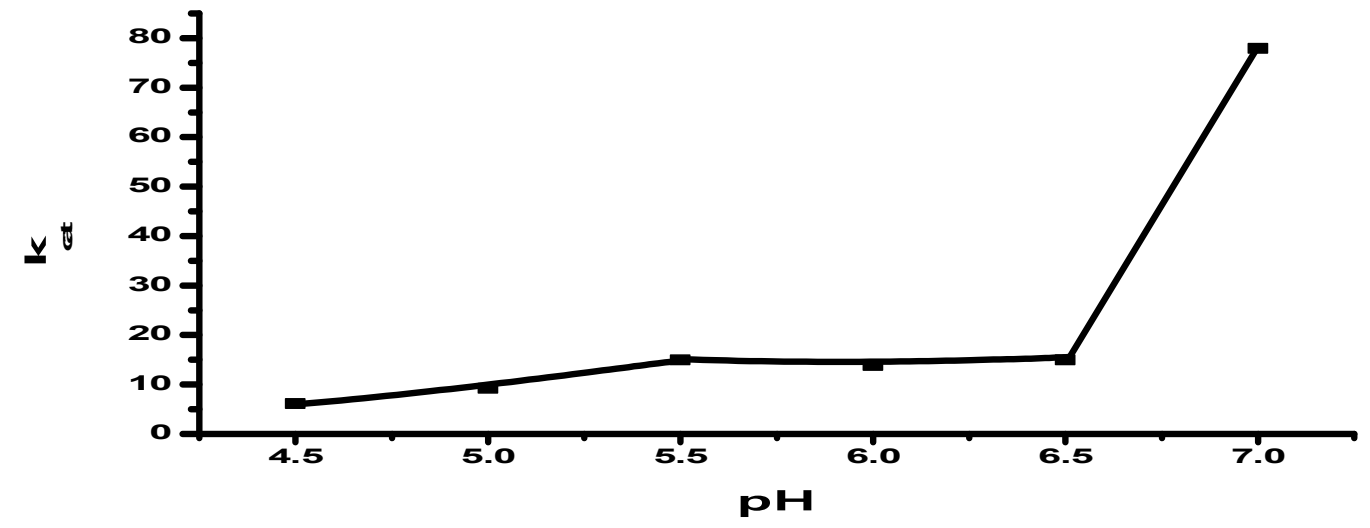

Fig.-4: Effect of $\mathrm{pH}$ on Reaction Rate

Conditions: $[\mathrm{OAP}] \times 10^{4}=0.2 \mathrm{M},\left[\mathrm{KHSO}_{5}\right] \times 10^{4}=2.0 \mathrm{M}, \lambda_{\max }=434 \mathrm{~nm}$, Temperature $=32 \pm 0.1^{\circ} \mathrm{C}$

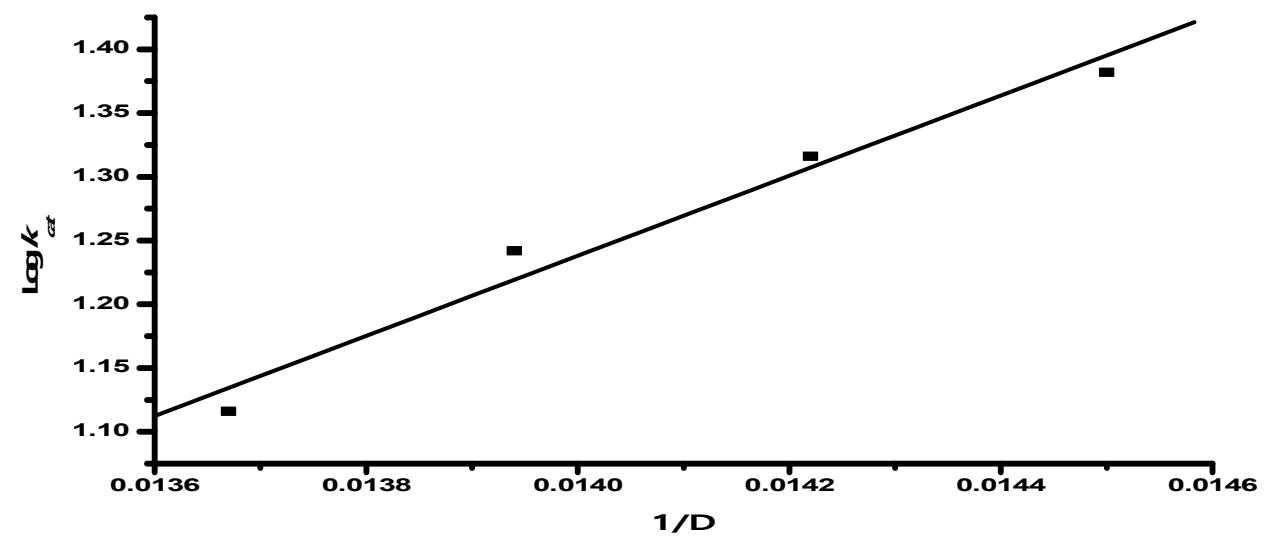

Fig.-5: Effect of Dielectric Constant on Reaction Rate

Conditions: $[\mathrm{OAP}] \times 10^{4}=0.4 \mathrm{M},\left[\mathrm{KHSO}_{5}\right] \times 10^{4}=4.0 \mathrm{M}, \mathrm{pH}=7.0, \lambda_{\max }=434 \mathrm{~nm}, \mathrm{Temp} .=32 \pm 0.1^{\circ} \mathrm{C}$

\section{Effect of Ions}

The present study shows that removal of OAP from wastewater in the presence of other cations like $\mathrm{Na}^{+}$, becomes easy. We had studied this by taking $\mathrm{Na}^{+}$in the form of $\mathrm{NaCl}$ and varying the concentrations of $\mathrm{Na}^{+}$in the reaction mixture. The results are shown in Fig.-6. It can be seen that as the concentration of $\mathrm{Na}^{+}$ increases, the rate of removal of OAP also increases. The maximum rate of this removal process is found at $0.5 \mathrm{M}$ concentration of ions in the $\mathrm{NaCl}$ solution.

\section{Effect of Temperature}

To determine the optimum temperature, experiments were performed in a series. The range followed was 25 to $40^{\circ} \mathrm{C}$. It was observed that below $32^{\circ} \mathrm{C}$, the activation energy required for the reaction to proceed was not enough, although oxone had some rate constant of decomposition. As the temperature reached to $32^{\circ} \mathrm{C}$, the decomposition rate became maximum ${ }^{49}$. Since low temperature favors the degradation by $\mathrm{KHSO}_{5}$ when the medium is buffered by phosphate ${ }^{49}$, hence the variation was allowed below $40^{\circ} \mathrm{C}$. It was observed that increasing temperature, increased the rate of degradation of OAP. The activation energy for the present study was calculated to be $74.096 \mathrm{~kJ} / \mathrm{mol}$. This was compared to other compounds, degraded by $\mathrm{KHSO}_{5}$. For example; glycine and alanine are having activation energies as $112.13 \mathrm{~kJ} / \mathrm{mol}$ and $101.67 \mathrm{~kJ} / \mathrm{mol}^{55}$. 
RASĀYAN J. Chem.

Vol. 13 | No. 3 |1424-1437| July - September | 2020

The values of rate constants were determined at four different temperatures $\left(32.0-38.0^{\circ} \mathrm{C}\right)$ by the Arrhenius plot which is shown in Fig.-7.

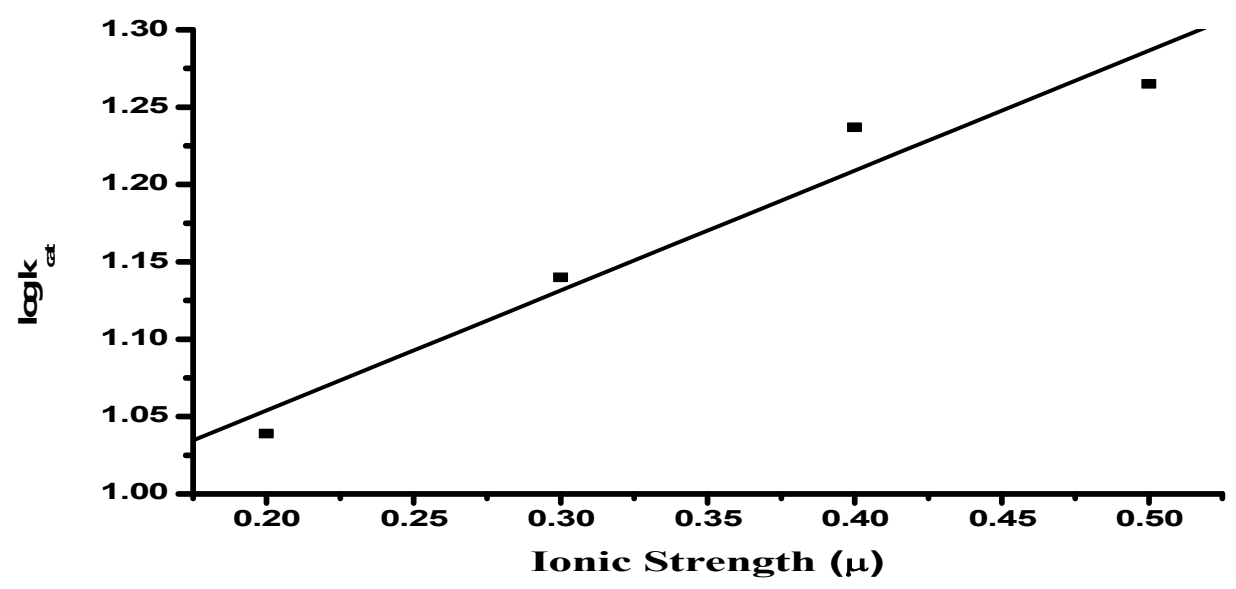

Fig.-6: Effect of Ionic Strength on Reaction Rate

Conditions: $[\mathrm{OAP}] \mathrm{X} 10^{4}=0.4 \mathrm{M},\left[\mathrm{KHSO}_{5}\right] \mathrm{X} 10^{4}=4.0 \mathrm{M}, \mathrm{pH}=7.0, \lambda_{\max }=434 \mathrm{~nm}, \mathrm{Temp} .=32 \pm 0.1^{\circ} \mathrm{C}$

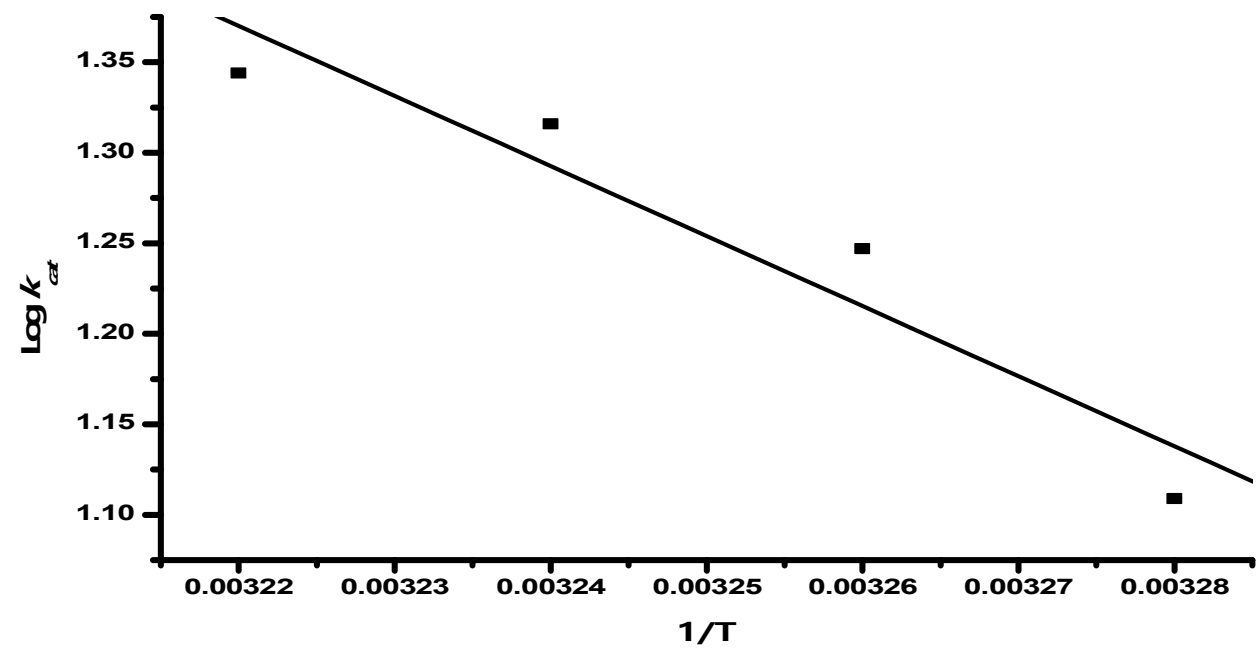

Fig.-7: Arrhenius Plot

Conditions: $[\mathrm{OAP}] \mathrm{X} 10^{5}=2.0 \mathrm{M},\left[\mathrm{KHSO}_{5}\right]$ X $10^{4}=2.0 \mathrm{M}, \mathrm{pH}=7.0, \lambda_{\max }=434 \mathrm{~nm}$

The study of all the thermodynamic parameters calculated for the removal of OAP by using $\mathrm{KHSO}_{5}$ confirms that the reaction is characterized by a comparatively low value of activation energy $(E a)$. Other thermodynamic parameters like Enthalpy of activation $(\Delta H)$ and value of Arrhenius parameter were also calculated from the slope and intercept of a graph plotted between $\log k_{c a t}$ versus $1 / T$ and shown in Fig.-7. The formulas applied for the determination of these parameters have already discussed earlier. Table- 2 shows the values of all these parameters. The positive value of enthalpy of activation $(\Delta H)$ is evidence for the endothermic process of oxidation of OAP. The negative value of entropy of activation $(\Delta S)$ indicates the decrease in the randomness of particles during the oxidation process which further promotes the formation of the product. This high value also suggests the involvement of solvent interactions ${ }^{56}$. The low positive value of activation energy $(E a)$ indicates the bi molecularity of the process. It can also be assumed that the oxidizing power of oxone i.e. $\mathrm{KHSO}_{5}$ is very much responsible to decrease the minimum required 
RASĀYAN J. Chem.

Vol. 13 | No. 3 |1424-1437| July - September | 2020

energy for the reaction. Hence, $\mathrm{KHSO}_{5}$ seems to be very effective for the removal of OAP in a low-cost effective way. Moreover, the value of the pre-exponential factor $(A)$ gives an idea of the number of times the reacting species collide with each other. The high value of Helmholtz free energy $(\Delta F)$ is evidence for the high rate of reaction. The high value indicates the high internal energy of OAP and that of $\mathrm{KHSO}_{5}$, due to which the collision frequency is also high and hence, effective collision is again high. This may be one of the reasons for the swift rate of the reaction.

Table-2: Kinetic Parameters for Peroxymonosulphate Oxidation of OAP $[\mathrm{OAP}] \times 10^{5}=2.0 \mathrm{M},\left[\mathrm{KHSO}_{5}\right] \times 10^{4}=2.0 \mathrm{M}, \mathrm{pH}=7.0, \lambda_{\max }=434 \mathrm{~nm}$

\begin{tabular}{c|c|c|c|c|c|c}
\hline $\begin{array}{c}\text { Temp. } \\
\left({ }^{\circ} \mathrm{C}\right)\end{array}$ & $\begin{array}{c}\mathrm{k}_{\mathrm{cat}} \\
\left(\mathrm{dm}^{3} \mathrm{~mol}^{-1} \mathrm{~s}^{-1}\right)\end{array}$ & $\begin{array}{c}\mathrm{Ea} \\
\left(\mathrm{kJmol}^{-1}\right)\end{array}$ & $\begin{array}{c}\mathrm{A} \mathrm{X} \mathrm{10} \\
\left(\mathrm{dm}^{3} \mathrm{~mol}^{-1} \mathrm{~s}^{-1}\right)\end{array}$ & $\begin{array}{c}-\Delta \mathrm{S}^{\#} \\
\left(\mathrm{Jmol}^{-1} \mathrm{~s}^{-1}\right)\end{array}$ & $\begin{array}{c}\Delta \mathrm{H}^{\#} \\
\left(\mathrm{kJmol}^{-1}\right)\end{array}$ & $\begin{array}{c}\Delta \mathrm{F}^{\#} \\
\left(\mathrm{kJmol}^{-1}\right)\end{array}$ \\
\hline 32 & 12.858 & - & 1.577042624 & 10.85770946 & 25.90358686 & 29.71398407 \\
\hline 34 & 17.655 & 123.42628650 & 1.806276293 & 11.84376560 & 25.88695964 & 29.73913383 \\
\hline 36 & 20.725 & 63.23053871 & 1.772870085 & 13.09474480 & 25.87033243 & 29.76428358 \\
\hline 38 & 22.070 & 25.12227445 & 1.582160049 & 14.50329563 & 25.85370521 & 29.78943340 \\
\hline $\begin{array}{c}\text { Mean } \\
\text { Values }\end{array}$ & & 70.59303323 & 1.684587263 & 12.57487879 & 25.87864604 & 29.75170871 \\
\hline
\end{tabular}

Ea from graph: $74.0959458 \mathrm{~kJ} / \mathrm{mol}$

\section{Comparison of Uncatalyzed Monopersulfate Oxidation of OAP with Previously Applied Methods}

Several methods were applied for the removal of OAP from water samples. In these processes, several metals like $\mathrm{Cu}$ (II), $\mathrm{Co}$ (II), $\mathrm{Ti}$ as $\mathrm{TiO}_{2}, \mathrm{Ag}$ as $\mathrm{Ag}$ electrode, and Pt as Pt electrode have been used. The use of copper as a catalyst is more pronounced as compared to other metals may be due to its low cost, but on the other hand, some serious diseases like Wilson disease and Minimata can be credited to copper. Hence, it seems to be a toxic alternative and is not an eco-friendly catalyst. Although the use of cobalt does not lead to any toxicity but in respect of expenditure, it is comparatively much costly. The use of tyrosinase, hemoglobin, catalase, etc also seems to be comparatively costly. The cost of Ag and Pt electrodes is also very high. Ozone itself acts as a bleaching agent and its solution contains toxicity, hence its use at a commercial scale must be thought twice. Wet air oxidation seems to be eco-friendly, but it works at very high temperature and pressure. Hence, it can be followed only at specific conditions only under controlled conditions in expert hands.

Now, the present method seems to be more favorable in all respects as compared to the other methods discussed previously. All the chemicals used in this method, are easily available. All of them are cheap enough to use at the commercial level. They all are eco-friendly i.e. free of any toxicity, both in respect of their own or their solution. Due to the strong oxidizing property of oxone, the reaction completes in a very short period. Most importantly, the reaction can be easily proceeded at low temperatures, even at room temperature also, as compared to other methods. Thus, this method seems to be eco-friendly, can be performed at low operational cost at an industrial scale, and completes in a very short period.

\section{Comparative Review}

Various methods have been reported which deal with the removal of pollutants by generating sulfate radicals $^{55,57-60}$. These methods can be compared with the present study in Table-3, since it also involves the reaction between sulfate radicals and OAP during the reaction.

Table-3: Comparison of Results

\begin{tabular}{c|c|c}
\hline Authors & Target Compound & Activation Energy \\
\hline S. M. Rayappan et al. & Glycine $^{55}$ & $112.13 \mathrm{~kJ} / \mathrm{mol}$ \\
\hline S. M. Rayappan et al. & Alanine $^{55}$ & $101.67 \mathrm{~kJ} / \mathrm{mol}$ \\
\hline Y. Ji et al. & Atrazine $^{57}$ & $97.98 \mathrm{~kJ} / \mathrm{mol}$ \\
\hline C. Tan et al. & Diuron $^{58}$ & $166.7 \pm 0.8 \mathrm{~kJ} / \mathrm{mol}$ \\
\hline A. Ghauch et al. & Naproxen $^{59}$ & $155 \pm 26.4 \mathrm{~kJ} / \mathrm{mol}$ \\
\hline A. Ghauch et al. & Bisoprolol $^{60}$ & $119.8 \pm 10.8 \mathrm{~kJ}$ \\
\hline Present Study & $\begin{array}{c}\text { Ortho } \\
\text { Aminophenol }\end{array}$ & $74.096 \mathrm{~kJ} / \mathrm{mol}$ \\
\hline \multicolumn{3}{|c}{1434}
\end{tabular}


RASĀYAN J. Chem.

Vol. 13 | No. 3 |1424-1437| July - September | 2020

\section{CONCLUSION}

In this study, uncatalyzed potassium mono persulfate oxidation of OAP was carried out to develop a method for its removal from water samples affected by it. To identify the optimum levels of different operating parameters, a kinetic spectrophotometric study was conducted in a phosphate-buffered medium. The results revealed that the removal of OAP by using monopersulfate, follows fractional-order kinetics concerning substrate and oxidant both and follows overall first-order kinetics. It is an endothermic process for which the value of activation energy is found to be $74.096 \mathrm{~kJ} / \mathrm{mol}$, which is comparatively low. The optimum values of $\mathrm{pH}$ and temperature were 7.0 and 32 to $38 \pm 0.1^{\circ} \mathrm{C}$. The product formed due to oxidation of OAP is Questiomycin A, which is used to synthesize Actinomycin D, an anti-neoplastic agent, which is used in the treatment of tumors. This method could not only prove instrumental in the research about the treatment of deadly disease of cancer but also can form the basis of an effective method of removal of aminophenols in water samples having a hazardous concentration of this pollutant in it which might lead to some serious health problems as far as the human race is concerned. Further insight into this method is still being explored by us to make this more effective. Moreover, the ease of availability of all the chemicals, their non-toxicity, and low cost, insists this way of removal of OAP be performed at the laboratory as well as in industrial scale.

\section{ACKNOWLEDGMENT}

The author would like to thank the of Chemistry, Kanya Gurukul Campus, Gurukul Kangri Vishwavidyalaya, Hardwar, for providing all the necessary facilities for completing this work.

\section{REFERENCES}

1. S. P. Dharupaneedi, S.N. Kotrappanavar, M. Nadagouda, K. Raghava Reddy, S.S. Shukla and T.M. Aminabhavi, Separation and Purification Technology (2018), DOI: 10.1016/j.seppur.2018.09.003

2. P. Sarma, Asian Journal of Chemistry, 27(1), 325(2015), DOI: 10.14233/ajchem.2015.17826.

3. C.V. Reddy, I.N. Reddy, B. Akkinepally, V.V.N. Harish, K.R. Reddy and S. Jaesool, Ceramics International, 45, 15298(2019), DOI:10.1016/j.ceramint.2019.05.020.

4. K.R. Reddy, M. Hassan and V.G. Gomes, Applied Catalysis A: General, 489, 1(2015), DOI: org/10.1016/j.apcata.2014.10.001

5. S. Valliammai, Y. Subbareddy and B. Jeyaraj, Indian Journal Of Chemical Technology, 24(2), 134(2017).

6. A.K. Asiagwu, H.I. Owamah and V.O. Illoh, Advances in Applied Science Research, 3(4), 2257(2012).

7. D.A. Yaseen and M. Scholz, International Journal of Environmental Research, 13, 367(2019), DOI: 10.1007/s41742-019-00180-1.

8. P. Asaithambi, E. Alemayehu, B. Sajjadi and A.R.A. Aziza, Water Resources and Industry, 18, 17(2017).

9. A. Mehta, A. Mishra, S. Basu, N.P. Shetti, K.R. Reddy, T.A. Saleh and T.M. Aminabhavi, Journal of Environmental Management, 250, 109486 (2019), DOI:10.1016/j.jenvman.2019.109486.

10. S.K. Sen, P. Patra, C.R. Das and S. Raut, Water Resources and Industry, 21, 100106(2019), DOI: 10.1016/j.wri.2019.100106.

11. New Jersey Department of Health and Senior Services Hazardous Substance Fact Sheet (2007).

12. Sittig's Handbook of Toxic and Hazardous Chemical Carcinogens. 5th edition, William Andrew, Norwich, NY, A-H, I-Z, 137(2008).

13. C. Huber, B. Bartha, R. Harpaintner and P. Schroder, Environmental Science and Pollution Research, 16, 206(2009), DOI:10.1007/s11356-008-0095-z.

14. M. Megharaj, H.W. Pearson and K. Venkataswarlu, Pesticide Biochemistry and Physiology, 40(3), 266(1991), DOI: 10.1016/0048-3575(91)90098-7.

15. C. Olmazu, M. Puiu, I. Babaligea, A. Raducan and D. Oancea, Applied Catalysis A, 447, 74(2012), DOI: 10.1016/j.apcata.2012.09.009.

16. U. Hollstein, Chemical Reviews, 74, 625(1974), DOI:10.1021/cr60292a002.

17. E. Katz and H. Weissbach, Journal of Biological Chemistry, 237, 882(1962).

18. E. Frei, Cancer Chemother Rep., 58(1), 49(1974). 
19. T. Horvath, J. Kaizer and G. Speier, Journal of Molecular Catalysis A-Chemical, 215, 9(2004), DOI: 10.1016/j.molcata.2004.01.006.

20. M. Puiu, A. Raducan and D. Oancea, Analele Universitatii Bucuresti : Chimie, 55(6), 426 (2004).

21. M. Hassanein, M. Abdo, S. Gerges and S. El-Khalafy, Journal of Molecular Catalysis A: Chemical, 287(1) , 53(2008), DOI: 10.1016/j.molcata.2008.03.002.

22. T. Nogami, T. Hishida, M. Yamada, H. Mikawa and Y. Shirota, The Bulletin of the Chemical Society of Japan, 48, 3709 (1975).

23. C. Washington, J. Maxwell, J. Stevenson, G. Malone, E.W. Lowe Jr., Q. Zhang, G. Wang and N.R. McIntyre, Archives of Biochemistry and Biophysics, 557-558, 24(2015), DOI: 10.1016/j.abb.2015.04.007.

24. D. Oancea and M. Puiu, Central European Journal of Chemistry, 1, 233(2003), DOI: 10.2478/BF02476226.

25. A. Kudelski and J. Bukowska, Journal of Molecular Structure, 275, 145(1992), DOI:10.1016/00222860(92)80190-S.

26. H.J. Salavagione, J. Arias-Pardilla, P.G. Terradillos and J.L.V. Pico, Journal of Electroanalytical Chemistry, 565(2), 375(2003), DOI:10.1016/j.jelechem.2003.11.005.

27. R.L. Tseng, F.C. Wu and R.S. Juang, Carbon, 41, 487(2003), DOI:10.1016/S0008-6223(02)00367-6.

28. A.K. Asiagwu, H.I. Owamah and V.O. Illoh, Advances in Applied Science Research, 3(4), 2257(2012).

29. V.K. Gupta, D. Mohan, Suhas and K.P. Singh, Industrial \& Engineering Chemistry Research, 45, 1113(2006), DOI:10.1021/ie051075k.

30. A.J. Barik and P.R. Gogate, Ultrasonics Sonochemistry, 28, 90(2016), DOI: 10.1016/j.ultsonch.2015.07.001.

31. F.J. Rivas, Garcia-Araya JF, Garcia R and O. Gimeno, Journal of Hazardous Materials, 153, 792(2007), DOI: 10.1016/j.jhazmat.2007.09.025.

32. Wp-content on Caroat by UNITED -INITIATORS, dated on 08/2017.

33. J. Bernadou, M. Bonnafous, G. Labat, P. Loiseau and B. Meunier, Drug Metabolism \& Disposition, 19(2), 360(1991).

34. F.J. Rivas, O. Gimeno and T. Borallho, Chemical Engineering Journal, 192, 326(2012), DOI:10.1016/j.cej.2012.03.055.

35. R.D. Kaushik, P. Rathi, Manila, J. Singh and R. Yadav, Journal of Chemical and Pharmaceutical Research, 6(7), 2752(2014).

36. J.C.E. Yang, B. Yuan, S. Wang and M.L. Fu, Applied Catalysis B-Environmental, 14, 23(2017).

37. S. Munusamy, V.P. Muralidharan and S.K. Iyer, Tetrahedron Letters, 58(6), 520(2017), DOI: 10.1016/j.tetlet.2016.12.072

38. K. Xiao, Y. Chen, Y. Zhou, W. Zhu, Y.W. Seow, Q. Yang and X. Jiang, Water Research, 122, 492(2017).

39. N. Soldatova, Postnikov, M.S. Yusubov, O. Kukurina, V.V. Zhdankin, A. Yoshimura and T. Wirth, M.S.Yusubov, Chemistry Open, 6(1), 18(2017), DOI: 10.1002/open.201600129.

40. A.I. Vicente, J.A.S. Coelho, C.A.M. Afonso, S.P. Simeonov, H.I. Lazarova and M.D. Popova, Molecules, 22(2), 329 (2017), DOI: 10.3390/molecules22020329.

41. V. Sriramoju, R. Jillella, S. Madabhushi and S. Kurva, Chemistry Letters, 46(4), 560(2017), DOI: 10.1246/cl.161171.

42. A. Iturmendi, M. Iglesias, J. Munárriz, V. Polo, J.J. Pérez-Torrente and L.A. Oro, Chemical Communications, 53, 404(2017), DOI:10.1039/C6CC09133D.

43. K.R. Reddy, P. Kannaboina and P. Das, Asian Journal of Organic Chemistry, 6(5), 534(2017), DOI: $10.1002 /$ ajoc.201600530.

44. M.M. Najafpour and N.J. Moghaddam, New Journal of Chemistry, 41(5), 1909(2017), DOI: $10.1039 /$ C6NJ02842J.

45. M. Anbia and M. Rezaie, Research on Chemical Intermediates, 43(1), 245(2017), DOI: 10.1007/s11164-016-2618-4.

46. H.Y. Shu, S.W. Huang and M.K. Tsai, Desalination of Water Treatment, 57(60), 29517(2016), DOI: 10.1080/19443994.2016.1172031. 
RASĀYAN J. Chem.

Vol. 13 | No. 3 |1424-1437| July - September | 2020

47. T. Swamy, P. Raviteja, G. Srikanth, B.V.S. Reddy and V. Ravinder, Tetrahedron Letters, 57(50), 55965598(2016), DOI: 10.1016/j.tetlet.2016.10.110.

48. F.J. Rivas, F.J. Beltrán, F. Carvalho and P.M. Alvarez, Industrial \& Engineering Chemistry Research, 44(4), 749(2005), DOI: 10.1021/ie0401511.

49. D.L. Ball and J.O. Edwards, Journal of the American Chemical Society,78(6), 1125(1956), DOI: 10.1021/ja01587a011.

50. E.A. Guggenheium, Philosophical Magazine, 2, 538(1926), DOI: 10.1080/14786442608564083.

51. M. Puiu and D, Oancea, Analele UniversităNii din Bucuresti - Chimie, Anul XIII (serie nouă), Vol. III, pp. 263-268 (2004).

52. M. Puiu, A. Răducan and D. Oancea, Revue Roumaine de Chimie, 52(11), 1039(2007).

53. R.D. Kaushik, R. Malik, Manila, and A. Kumar, Asian Journal of Chemistry, 22(3), 2090(2010).

54. E.S. Amis, Academic Press, New York (1966), DOI:10.1002/ange.19680800421.

55. S.M. Rayappan, D. Easwaramurthy, M. Palanichamy and V. Murugesan, Inorganic Chemistry Communications, 13, 131(2007).

56. R.D. Kaushik, J. Singh, Manila, P. Tyagi and P. Singh, Journal of Indian Chemical Society, 99, 1483(2014).

57. Y. Ji, C. Dong, D.Kong et al., Chemical Engineering Journal, 263, 45(2015), DOI: 10.1016/j.cej.2014.10.097.

58. C. Tan, N. Gao, Y. Deng et al., Chemical Engineering Journal, 203, 294(2012).

59. A. Ghauch, A.M. Tuqan and N. Kibbi, Chemical Engineering Journal, 279, 861(2015), DOI: 10.1016/j.cej.2015.05.067.

60. A. Ghauch and A.M. Tuqan, Chemical Engineering Journal, 183, 162(2012), DOI: $10.1016 /$ j.cej.2011.12.048.

[RJC-5771/2020] 